ДЕГРАДАЦІЯ, МЕТРОЛОГІЯ І СЕРТИФІКАЦІЯ СЕНСОРІВ

SENSOR'S DEGRADATION, METROLOGY AND CERTIFICATION

UDC 5.082.73

\title{
LASER INSTALLATION FOR THE MEASUREMENT OF THE ACOUSTIC FIELDS PARAMETERS ON THE SURFACE OF ACOUSTIC WAVE GUIDES
}

\author{
I. V. Blonsky, Ya. I. Lepikh*, V. V. Semenov, V. G. Gryts, A. V. Stronski** \\ Institute of Physics NAS Ukraine, 03028, Kyiv-28, prosp. Nauki, 46, tel. (044) 525-98-10 \\ fax. (044) 525 1589, e-mail: blon@iop.kiev.ua \\ * - I.I.Mechnikov Odessa national university, e-mail: ndl_lepikh@onu.edu.ua \\ ** - V.Lashkaryov Institute of Semiconductor Physics, NAS Ukraine, pr. Nauki,41, 03028, Kyiv
}

\section{LASER INSTALLATION FOR THE MEASUREMENT OF THE ACOUSTIC FIELDS PARAMETERS ON THE SURFACE OF ACOUSTIC WAVE GUIDES}

\section{V. Blonsky, Ya. I. Lepikh, V. V. Semenov, V. G. Gryts', A. V. Stronski}

\begin{abstract}
For the first time the possibility of the development and fabrication of the design nondetuned functional optical scheme of the laser heterodyne installation intended for the investigation of the amplitude and phase fields of surface acoustic waves (SAW). The design is characterized not by separate optical elements but the presence of the two units - probe unit and photo-sensor with minimal number of optical elements. This enabled to reduce errors during amplitude and phase measurements, because the installation setup provides high sensitivity to the small amplitude of SAW and good reproducibility of the results. The optical scheme of the device is presented operation principle is described as well as the results of some investigations.
\end{abstract}

Keywords: surface acoustic waves, heterodyne method, amplitude, phase

\section{ЛАЗЕРНА УСТАНОВКА ДЛЯ ВИМІРЮВАННЯ ПАРАМЕТРІВ АКУСТИЧНОГО ПОЛЯ НА ПОВЕРХНІ АКУСТОПРОВОДІВ}

\section{І. В. Блонський, Я. І. Лепіх, В. В. Семенов, В. Г. Гриц, О. В. Стронський}

Анотація. Вперше показана можливість розробки та створення стійкої відносно дії дестабілізуючих факторів функціональної оптичної схеми лазерної гетеродинної установки, призначеної для дослідження амплітудних і фазових полів поверхневих акустичних хвиль (ПАХ). Вона виконана не окремими оптичними елементами, а зібрана $з$ двох узлів - вузол зонда і вузол фотоприймача з мінімальним числом оптичних елементів. Це дало змогу зменшити похибку при проведенні амплітудних та фазових вимірів, оскільки установка забезпечує високу чутливість до малих амлітуд ПАХ і хорошу відтворюванність результатів. Наводиться оптична схема, викладено принцип дії установки, надаються результати деяких досліджень.

Ключові слова: поверхневі акустичні хвилі, гетеродинний метод, амплітуда, фаза 


\title{
ЛАЗЕРНАЯ УСТАНОВКА ДЛЯ ИЗМЕРЕНИЯ ПАРАМЕТРОВ АКУСТИЧЕСКОГО ПОЛЯ НА ПОВЕРХНОСТИ АКУСТОПРОВОДОВ
}

\author{
И. В. Блонский, Я. И. Лепих, В. В. Семенов, В. Г. Гриц, А. В. Стронский
}

Аннотация. Впервые показана возможность разработки и создания устойчивой относительно дестабилизирующих факторов функциональной оптической схемы лазерной гетеродинной установки для исследования амплитудных и фазовых полей поверхностных акустических волн (ПАВ). Установка выполнена не отдельными оптическими элементами а собрана из двух узлов - узла зонда и узла фотоприемника с минимальным количеством элементов. Это дало возможность уменьшить ошибку при проведении амплитудных и фазовых измерений, поскольку установка обеспечивает высокую чувствительность к малым амплитудам ПАВ и хорошую воспроизводимость результатов. Приводится оптическая схема, изложен принцип действия установки, представлены результаты некоторых исследований.

Ключевые слова: поверхностные акустические волны, гетеродинный метод, амплитуда, фаза

\section{Introduction}

At present time optical methods, optical acoustic methods, including using surface acoustic waves (SAW), are widely used for the effective control of different parameters [1,2], for laser diagnostics of acoustic fields in liquid and gases, in medical diagnostics, for the characterization of scattering media, acousto-optic visualization in turbid media, etc.

The known installations for the precise measurements of the SAW parameters usually are of heterodyne type. It is one of the best methods for the solutions of many research tasks in the development of the new elements and acousto-electronic devices using SAW. The basics of the heterodyne method are described in [3,4], also it was discussed in review work [5]. Practical realization in different electronic and optical schemes was described in [6-10]. As the advantages of the heterodyne method it is necessary to note non-sensitivity to the fluctuations during phase measurements, high sensitivity to the small SAW amplitudes and also wide band of used frequencies.

The aim of the present work was to provide the decrease of the measurements error for the control of surface acoustic waves, increase of the amplitude sensitivity and phase reproducibility of the laser installation for the measurements of the surface acoustic waves in the $10-100 \mathrm{MHz}$ range.

The main drawbacks of the method: the complexity of the electronic scheme, the necessity of the rigid collinearity of rays. Also the interference pattern on the photo-sensor is eroded which leads to the measurements instability. In heterodyne setup the four-arm diffraction scheme is used, which leads to the increase of the optical paths of the laser rays. And because many separate optical elements are used the measurement setup becomes structurally detuned. Below is described the highly-sensitive heterodyne installation which provides better technical characteristics as compared to the mentioned above and provides possibility of the carrying out of the complex measurements of different SAW devices. Such installation in sufficient extent is lacking the drawbacks of the known heterodyne installation of similar type.

\section{Measurement laser installation}

Functional scheme of installation is shown in fig.1. Laser 1 (LG-38) through prism with two reflecting surfaces 2 supply heterodyne channel of installation by the monochromatic radiation $\left(\lambda_{0}=0.63 \mu \mathrm{m}\right)$; in acoustic modulator 3 (Bragg cell) the spatial-frequency separation of laser radiation due to Bragg diffraction takes place. Zero and first orders of diffraction are used. The direct beam of zero order is focused by microobjective 5 on the surface of investigated sample $\mathbf{6}$ with SAW. The reflected beam which contains information on the amplitude and phase of SAW is returned to the acoustic modulator and after diffraction on it goes to the receiving window of photodetector 9 .

Laser beam of the first order of diffraction is focused by the microobjective $\mathbf{8}$ on the surface of flat mirror 7 and returning through acousto-optical modulator goes to the receiving window of photodetector, thus forming heterodyne optical channel of installation that provides its with stable and contrast interference pattern.

In the photodetector which operates in the nonlinear regime the transformation of the optical signals into radiofrequency ones takes place: 


$$
2 f_{B} ; 2 f_{B}-f_{C} ; 2 f_{B}+f_{C},
$$

where $f_{B}-$ frequency of the acoustic excitation of the Bragg cell and $f_{C}-$ frequency of SAW. These signals contain information on the amplitude and phase of the SAW on the tested sample.

The change of SAW phase leads to sufficient requirements to the stability of the electrical lengths of the measurement and reference channels of installation. These requirements were satisfied by equalization of the channel optical lengths after acoustic modulator and design methods directed to their stabilization and minimization. Simultaneously by means of alignment of mirror 7 the collinearity of reference beam in direct and reverse directions was provided.

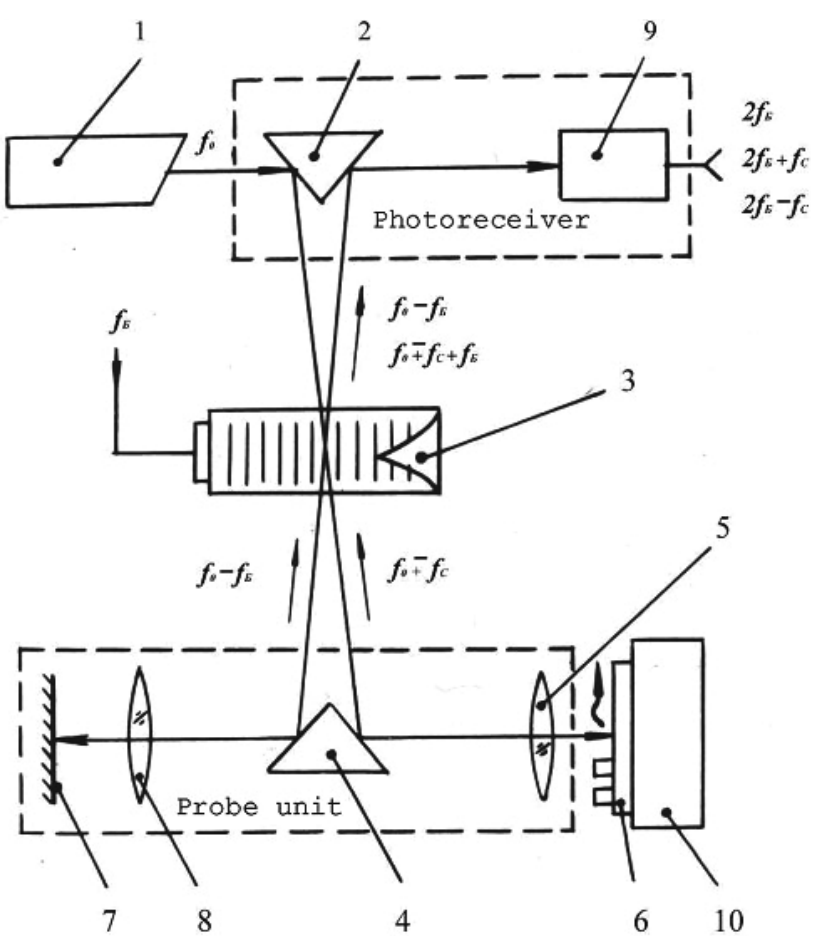

Fig. 1. Optical functional scheme of installation

Because diffraction angles are small the separation of the beams of zero and first orders of diffraction is provided in installation by the prism with two reflecting surfaces 4 . Such design measure sufficiently weakens the error influence of alignment of reflection elements on the accuracy of beams brining together in the receiving window of photodetector.

The described design of the scheme of optical probe enables to carry out investigations with the use of SAW in the wide frequency range. In the range of low frequencies the liquid Bragg cell is used in the optical setup of installation which operates on $28 \pm 3 \mathrm{MHz}$ excitation frequency.
For the frequencies more than $60 \mathrm{MHz}$ the solid state acousto-optic modulators are used.

For the precise alignment the cell is placed in alignment assembly. The criterium of the optimal alignment is the signal maximum at the output of photodetector (alignment limitations $\pm 5^{0}$ ). Similar alignment assemblies also are present in probe channel mirror and in object table $\mathbf{1 0}$, where the investigated sample is placed. The linear mechanical displacement of table is transformed into electric signal which is supplied at the input " $X$ " of the recorder.

Information about amplitude and phase of SAW is separated by means of photodetector signals processing by the electronic unit which represents itself the two-channel superheterodyne receiver with joint for both channels cascade of automatic amplification control (AAC). In the receiving unit the two signals are processed: $2 f_{B}$. and $2 f_{B}+f_{C}$. The peculiarity of the functional scheme is the use of the additional mixture in the second channel for the signal frequency lowering $\left(2 f_{B}+f_{C}\right)$ up to $2 f_{B}$ frequency. and also application of the similar type amplifiers of the intermediate frequency (AIF) for the $2 f_{B}$ frequency in both channels.

Acoustic modulators with operation frequencies $28 \pm 3 \mathrm{MHz}, 60 \pm 3 \mathrm{MHz}, 80 \pm 3 \mathrm{MHz}$ are used in installation; in accordance with the modulator frequency the respective AIF is installed in the receiving unit.

The out put signals of channels are reduced to the standard $465 \mathrm{kHz}$ frequency by lowering frequency changers and respective heterodynes which are part of AIF set. These signals are supplied to the input of the standard phase meter FK2-12, which measures SAW phase. Signal of SAW amplitude represents itself the voltage change of AAC at the input of the receiving electron unit. Amplitude and phase profile SAW are registered by PDS -012 recorder (or PDP-4-002).

During measurements of amplitude and phase profiles the microobjectives were chosen in each separate case depending on the frequency range of the sample.

As the generator for the excitation of the SAW on the surface of the investigated sample 6 the generator G3-41 or G4-143 was used.

The presence of SAW from output oncoming pin converter was controlled by oscillograph S1-97.

The photoelectric multiplier FEU-28 and electronic unit 18ELU-FM were used as photoreceivers. 
The Bragg cell and solid state modulators were power supplied by following generators: G3-41, G3-19A and G4-143.

\section{Experiment}

In fig. 2 the SAW amplitude profile is presented as a example which was measured with the use of filter with $28 \mathrm{MHz}$ frequency at the distance $4 \mathrm{~mm}$ from oncoming pin converter (OPC). In fig. 3 and 4 the SAW phase profiles are presented. They enable to determine the SAW wavelength and its propagation velocity along the sample. and also (characteristic for all samples) the slope of SAW phase front respective to the pins at the output of exciting OPC and phase difference even for the optimal scheme of bus within the aperture of receiving OPC.

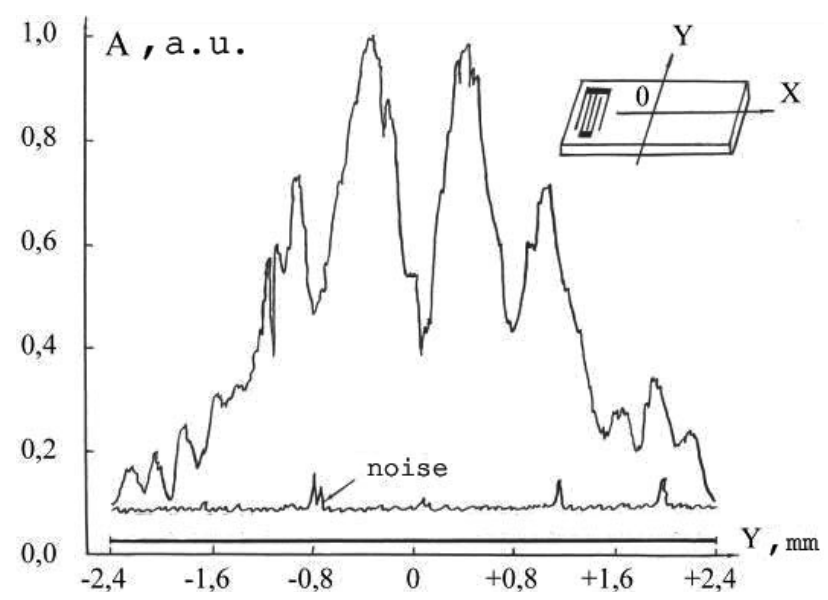

Fig. 2. SAW amplitude distribution in the transverse cross-section of filter

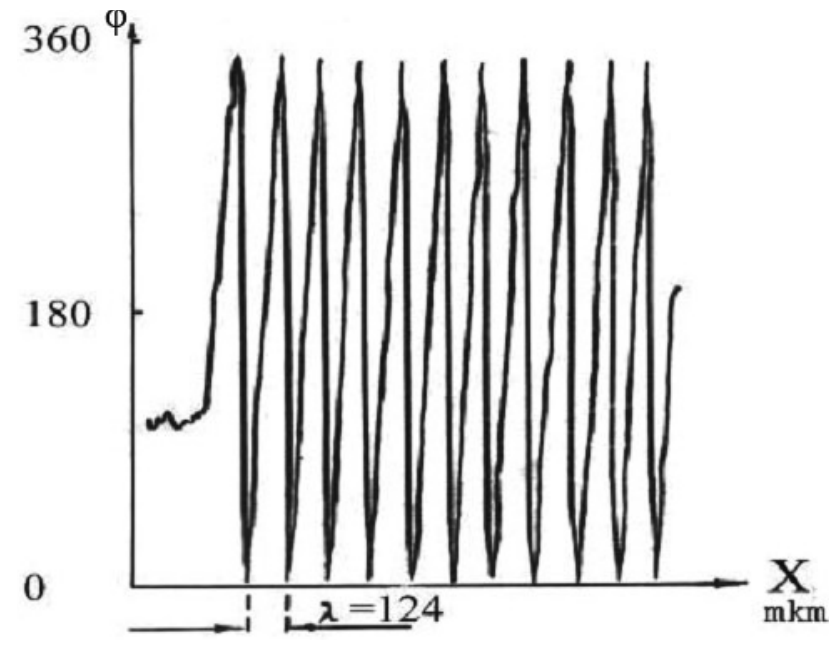

Fig. 3. Phase distribution on the filter along the SAW propagation direction

\section{Conclusions}

The scientific novelty of such design of laser installation is that for the first time:

1). Functional optical scheme of laser installation was designed using two separate units (not in separate optical elements) probe unit and photoreceiver unit. This enables to improve the collinearity of the brought together rays and to remove minimal detuning on angle of the signal and probe rays of heterodyne.

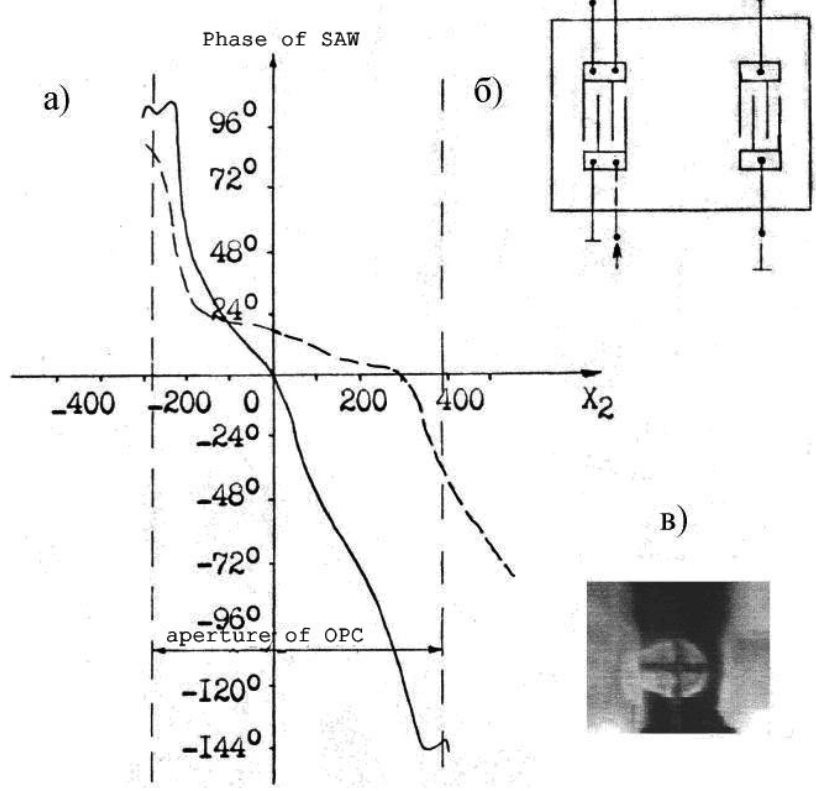

Fig. 4. a) comparison of the phase profiles of radiating OPC at different points of contact bus (dotted and solid lines are denoting the respective profiles in figure); b) schemes of at cutting-in; c) ultrasound welding of OPC output

2) In optical scheme of the laser installation instead of single flat mirrors the two prisms with top angle $72^{\circ}$ and two outside reflective surfaces are used and instead single lenses - microobjectives. The use of the prisms instead of mirrors enables to improve the design undetuning of the optical scheme. It is necessary to note that the angles between separate flat mirrors require tuning as during their assembly and well during operation of the device. By the use of microobjectives instead of lenses it was possible to eliminate aberrations and to improve focusing of laser radiation.

3) The use of the two prisms in the installation optical scheme enabled to obtain the short optical paths of the laser beams and these lead to the stability, reproducibility and measurement error reduction of the amplitude and phase measurements. La- 
ser installation becomes more compact as compared with the previous analogs. The installation become more universal during control of soundguides due to the use of minimal number of the optical elements it can be easily tuned and stable during operation. Also such closed design with two probes provides better protection from dust, moisture and external background light exposure.

The installation can be characterized by the following parameters:

frequency range of the investigated SAW 10$100 \mathrm{MHz}$;

SAW propagation velocity along the substrate with accuracy $\pm 1 \%$;

phase resolution $-3^{0}$.

Measurement of amplitude profiles - with accuracy $\pm 30 \mu \mathrm{m}$. $0.5 \mu m$.

Error of coordinate surveying of probing point -

Micro-cracks in piezo-ceramics were probed with the use of microobjective with spot diameter in focus $-4 \mu m$.

\section{References}

1. Semenov V.V., Blonsky I.V., Gryts V. G. Compact laser probe for surface acoustic wave, Semiconductor Physics Quantum Electronics \& Optoelectronics, 2010, v.13, № 1, P.84-86.

2. Antonov S.N., Rezvov Yu.G. High-efficiency multibeam Bragg acoustooptic diffraction with phase op- timization of multifrequency acoustic wave / J.Tech. Phys. - 2007. - V.77, N8. - P.93-100.

3. De la Rue R.M., Humphryes B.F., Mason I.M., Ash E.A. "SAW amplitude and phase measurements using laser probes", Proc. IEEE, 1972, 119, 2. P.117-126.

4. Whitman R.L., Korpel A. "Probing of Acoustic Surface Pertubation by Coherent Light", Appl. Opt.. -1969. - 8, 8. - P.1567-1576.

5. Stegeman G.I. "Optical probing of SAW and SAWdevices," IEEE Trans, 1976, SV-23, 1. - P.33-63.

6. Wickramasinhe H.K., Ash E.A. "Optical probing of SAW application to device diagnostics and to non-destructive testing" in Proc. of Symp. on optical and acoustic microelectronics. - 1975 I.23. P.413-431.

7. Jungeman R.L., Bower J.E., Green J.B., Kino G.S. "Fiber optic laser probe for acoustic wave measurements” Appl. Phys. Lett., 1982, 40,4. - P.313-315.

8. Grankin I.M., Gryts V.G., Ovsyannikov V.V. "laser installation for the measurement of phase and amplitude of the wave fields in the microstructures on the base of SAW" In book:"Problems of functional electronics" Gorky,1980. - P.123-124. (In Russian).

9. Britsyn K.N., Akpambetov V.B., Gryts V.G., Nikitin N.V. "Vizualization of SAW inacoustoelectronic devicees by the method of optical probing" Electronic technology, ser. 10 "Microelectronic devices" 1979, 3(15). - P.93-96. (In Russian).

10. Akpambetov V.B., Bzhezinsky A.D., Britsyn K.I., Gryts V.G. "Investigation of the band-pass filters on SAW by the method of optical probing" Electronic technology ser. "Radiocomponents" 1985 3(60). P.77-78. (In Russian). 